\title{
PENGARUH MODEL PEMBELAJARAN KOOPERATIF DAN TIPE KEPRIBADIAN TERHADAP HASIL BELAJAR PENDIDIKAN AGAMA BUDDHA SISWA
}

\author{
Rudi Hardjon ${ }^{1}$, Sahat Siagian ${ }^{2}$, R. Mursid ${ }^{3}$ \\ ${ }^{1}$ Guru SMA Swasta Sutomo Medan, Sumatera Utara, \\ ${ }^{2,3}$ Program Pascasarjana Universitas Negeri Medan \\ ${ }^{1}$ rudihardjon@gmail.com; ${ }^{2}$ sahat.sgn61@gmail.com; ${ }^{3}$ mursid.tp@gmail.com
}

\begin{abstract}
Abstrak: Penelitian kuasi eksperimen ini bertujuan untuk mengetahui: (1) perbedaan hasil belajar Pendidikan Agama Buddha antara siswa yang dibelajarkan dengan menggunakan Model Pembelajaran Kooperatif tipe Jigsaw dan tipe Number Head Together, (2) perbedaan hasil belajar siswa yang memiliki kepribadian tipe ekstrovert dan introvert, dan (3) interaksi antara model pembelajaran kooperatif dan tipe kepribadian dalam memengaruhi hasil belajar Pendidikan Agama Buddha.Pengujian hipotesis menunjukkan bahwa : (1) hasil belajar Pendidikan Agama Buddha siswa yang dibelajarkan dengan Model Pembelajaran Kooperatif tipe Jigsaw lebih tinggi dibandingkan dengan hasil belajar Agama Buddha siswa yang dibelajarkan dengan Model Pembelajaran Kooperatif tipe NHT dengan $F_{\text {hitung }}=6,548>F_{\text {tabel }}=3,96$ pada taraf signifikansi $\alpha=$ 0,05 dengan $d k=(1,76)$, (2) hasil belajar dengan kepribadian tipe ekstrovert lebih tinggi dari siswa dengan kepribadian tipe introvert, dan (3) terdapat interaksi antara penerapan model pembelajaran kooperatif dengan tipe kepribadian dalam memengaruhi hasil belajar Pendidikan Agama Buddha yaitu $F_{\text {hitung }}=40,70>F_{\text {tabel }}=3,96$ pada tingkat signifikansi $\alpha=0,05$ dengan $d k=$ $(1,76)$.
\end{abstract}

Kata Kunci: model pembelajaran, gaya berpikir sekuensial, hasil belajar bahasa jerman

Abstract: This quasi-experimental study aims to determine: (1) differences in learning outcomes of Buddhist Education between students who are taught using the Jigsaw Cooperative Learning Model and the Number Head Together type, (2) differences in learning outcomes of students who have extrovert and introverted personality types, and (3) the interaction between cooperative learning models and personality types in influencing the learning outcomes of Buddhist Religion Education. The testing of hypotheses shows that: (1) the learning outcomes of students of Buddhist Religion are taught by the Jigsaw Cooperative Learning Model is higher than the Religion learning outcomes Buddhist students who were taught by the NHT type of Cooperative Learning Model with $F_{\text {count }}=6.548>F_{\text {table }}=3.96$ at the significance level $\alpha=0.05$ with $d k=(1.76)$, (2) learning outcomes with extrovert type personality were higher than students with introvert type personality, and (3) there is an interaction between the application of mo del cooperative learning with personality type in influencing the learning outcomes of Buddhist Religion namely $F_{\text {count }}=40.70>$ $F_{\text {table }}=3.96$ at the significance level $\alpha=0.05$ with $d k=(1.76)$.

Keywords: learning model, sequential thinking style, German learning outcomes

\section{PENDAHULUAN}

Pembelajaran agama di Sekolah Menengah Atas (SMA) khususnya SMA Swasta Sutomo adalah suatu proses pembelajaran yang bermaksud memberikan dasar-dasar keagamaan kepada siswa tentang hidup beragama. Hidup beragama diartikan sebagai suatu sistem nilai tentang pengetahuan agama, sikap beragama, dan pengalaman keagamaan, sehingga dari pembelajaran terhadap nilai agama tersebut akan membentuk landasan akhlak, moral yang baik bagi siswa setelah tamat SMA.

Di SMA Swasta Sutomo 1 dan 2 sebenarnya para pendidik telah membuat beberapa metode pembelajaran yang berbeda dengan cara memberikan beberapa tugas yang harus diselesaikan siswa secara berkelompok seperti mengerjakan soal-soal latihan, membuat peta konsep dari setiap materi yang diajarkan, membuat kliping dari suatu materi tertentu. Akan tetapi, bila dilihat lebih spesifik, kegiatan 
kelompok hanya menyelesaikan tugas. Kegiatan Belajar Mengajar (KBM) tersebut biasanya lebih dikuasai oleh siswa yang pandai, sedangkan siswa yang kemampuannya rendah, kurang berperan dalam mengerjakan tugas kelompok. Akibatnya cara kerja kelompok seperti ini, siswa yang kemampuannya kurang memeroleh hasil belajar yang rendah dan adanya kesenjangan yang terlalu jauh antara hasil belajar siswa yang pandai dengan hasil belajar siswa yang kurang pandai.

Rendahnya hasil belajar PAB siswa tentunya disebabkan banyak faktor yang memengaruhinya, diantaranya adalah faktor eksternal dan faktor internal. Faktor eksternal adalah model pembelajaran yang dilaksanakan oleh pendidik atau guru, dan faktor internal adalah motivasi siswa. Menurut Wahyana (1986) faktor-faktor organisasi materi dan metode juga sangat menentukan dalam pencapaian berhasilnya KBM. Salah satu upaya yang dapat dilakukan adalah untuk meningkatkan kualitas pembelajaran yang digunakan guru selama ini pola penyampaiannya berpusat pada guru, sehingga siswa kurang termotivasi dan antusias untuk belajar. Hal tersebut mengakibatkan pelajaran kurang menarik serta guru juga tidak menunjukkan contoh-contoh lebih konkrit dalam pelajaran tersebut. Pembelajaran akan semakin efektif apabila model pembelajaran yang digunakan semakin sesuai dengan karakteristik siswa yang diajar, begitu juga tipe materi pelajaran itu sendiri (Gagǹe, 1979).

\section{Hasil Belajar Pendidikan Agama Buddha}

Belajar merupakan aktifitas yang paling utama dalam proses pendidikan untuk memeroleh ilmu pengetahuan. Tujuan pendidikan dapat tercapai karena tergantung pada efektifitas proses pembelajaran yang sangat berpengaruh terhadap cara guru untuk melaksanakan kegiatan pembelajaran yang akhirnya mempengaruhi aspek intelektual, perilaku, dan psikologis siswa. Belajar adalah suatu proses yang didalamnya terdapat satu perubahan, baik itu perubahan pada aspek pengetahuan, sikap maupun keterampilan. Belajar adalah proses berpikir yang menekankan kepada proses mencari dan menemukan pengetahuan melalui interaksi antara individu dan lingkungan (Sanjaya, 2008). Belajar merupakan suatu proses perubahan tingkah laku individu melalui interaksi dengan lingkungan (Hamalik, 2008).
Slameto (2010) menyatakan belajar adalah satu proses usaha yang dilakukan individu untuk memeroleh suatu perubahan tingkah laku yang baru secara keseluruhan, sebagai hasil pengalaman individu itu sendiri dalam interaksi dengan lingkungannya.

Skinner (dalam Dalyono, 1996) menyatakan bahwa belajar adalah proses penyesuaian tingkah laku ke arah yang lebih maju, ciri-ciri perubahan tingkah laku dalam pengertian belajar adalah (a) belajar merupakan suatu perubahan tingkah laku, perubahan itu dapat mengarah pada tingkah laku yang baik, tetapi juga ada kemungkinan mengarah kepada tingkah laku yang lebih buruk, (b) belajar merupakan suatu perubahan yang terjadi melalui latihan atau pengalaman, (c) untuk dapat disebut belajar, maka perubahan itu harus relatif mantap, harus merupakan akhir dari suatu periode waktu yang cukup panjang, dan (d) tingkah laku yang mengalami perubahan karena belajar menyangkut berbagai aspek kepribadian, baik fisik maupun psikis seperti perubahan dalam pengertian pemecahan suatu masalah, berfikir, keterampilan, kecakapan, kebiasaan atau moral.

Menurut Sri Dhammananda (2005), ajaran Buddha tercatat dalam banyak peristiwa sebagai terobosan besar bagi keadilan, prosedur demokrasi, dan kehormatan nilai-nilai moral dasar ajaran Buddha telah memberikan perilaku etika dasar diantara masyarakat yang menyerapnya dalam berbagai bentuk. Lebih lanjut Sri Dhammananda (2005), bahwa moral dalam ajaran Buddha bertujuan praktis menuntun manusia menuju kehidupan yang bertanggung jawab dalam keberuntungan dan kemalangannya sendiri. Keselamatan manusia adalah hasil dari pengembangan moralitas mereka sendiri dan tidak dapat diadakan atau diberikan pada seseorang oleh suatu perantara eksternal.

PAB menitikberatkan pada aspek moralitas yang ditemukan dalam semua prinsip kehidupan, dan dapat dirangkum dalam tiga prinsip dasar (terdapat dalam Dhammapada), yaitu (1) tak melakukan kejahatan, (2) perbanyak kebajikan, dan (3) mensucikan pikiran. Inilah nasihat yang diberikan oleh semua Buddha (Jan Sanjivaputta,1995).

PAB adalah suatu ajaran yang lebih dari suatu ajaran moral. Moralitas adalah langkah permulaan menuju tujuan hidup manusia yang sebenarnya (Narada,1998). Dalam Narada, Prof. Max Müller berpendapat bahwa ajaran moral 
agama Buddha adalah salah satu yang paling sempurna yang pernah dikenal di dunia ini. Sri Dhammananda (2004) mengatakan bahwa ajaran Buddha mengantarkan pada kemuliaan dan kesucian yang didasarkan pada normanorma moral, etika, intelektual, dan spiritual yang dipegang dan dijunjung tinggi dalam berhubungan satu dengan yang lain di dalam kehidupan sehari-hari.

Pendidikan Agama Buddha di SMA Kelas $\mathrm{X}$ semester 2 adalah membahas tentang Tiratana (terdiri dari tiga permata : Buddha, Dhamma, dan Saõgha). Buddha adalah guru para deva dan manusia sebagai pembimbing yang tiada taranya di alam semesta ini yang telah mencapai Penerangan Sempurna yang penuh welas asih mengabarkan ajaran yang telah ditemukan, Dhamma merupakan ajaran Kebenaran yang diajarkan Buddha kepada umat manusia untuk dijadikan pedoman, penuntun, dan petunjuk jalan kehidupan agar hidup lebih hidup dan bermanfaat bagi diri sendiri, orang lain, dan lingkungan, Saõgha adalah persamuhan para bhikkhu dan bhikkhuóî yang telah mencapai tingkat kesucian yang menjadi guru pembimbing dan spiritual umat manusia dalam penghidupan ini agar mengetahui kebenaran dan kebijaksanaan. Oleh karena itu, Tiratana merupakan pelindung bagi umat Buddha, yang dilandasi oleh tiga aspek, yakni aspek kemauan, aspek pengertian, dan aspek perasaan. Aspek kemauan yaitu memiliki kehendak dan kemauan sendiri untuk mencari tahu dan memahami serta dengan sadar bertindak aktif. Aspek pengertian yaitu memiliki pengertian yang benar bukan pengertian yang membuta tentang Tiratana sebelum menyatakan berlindung. Dan Aspek perasaan yaitu dorongan emosi yang timbul dari dalam diri dengan memiliki suatu perlindungan, percaya, bersyukur, dan penuh kasih, ikhlas, berbakti, dan mengabdi. Umat yang hendak menyatakan berlindung kepada Buddha, Dhamma, dan Saõgha dengan mengucapkan pernyataan berlindung dalam Buddha, Dhamma, dan Saõgha dengan mengucapkan Saraóagamana Pâöha.

\section{Model Pembelajaran Kooperatif Tipe Jigsaw} Menurut Slavin (1995) pembelajaran kooperatif tipe Jigsaw ini pertama kali dikembangkan oleh Aronson dkk. Pada model ini, kelas dibagi beberapa kelompok dengan 4 6 orang. Setiap kelompok oleh Aronson dinamai kelompok Jigsaw (gigi gergaji). Pelajaran dibagi dalam beberapa bagian sehingga setiap kelompok siswa memelajari salah satu bagian pelajaran tersebut. Model pembelajaran kooperatif tipe Jigsaw merupakan salah satu tipe model pembelajaran kooperatif yang mendorong siswa aktif dan saling membantu dalam menguasai materi pelajaran untuk mencapai prestasi yang maksimal.

Kunandar (2007) mengemukakan bahwa langkah-langkah tipe Jigsaw dalam tabel berikut :

Tabel 1. Langkah-Langkah Model Pembelajaran Kooperatif Tipe Jigsaw

\begin{tabular}{lll}
$\begin{array}{l}\text { Kelompok } \\
\text { Kooperatif }\end{array}$ & \multicolumn{2}{c}{ Tahap } \\
\hline Kelompok & I. & Siswa dibagi ke dalam kelompok kecil 4-6 siswa \\
\cline { 2 - 3 } & II. Guru membagikan wacana/tugas akademik yang sesuai dengan materi ajar \\
\cline { 2 - 3 } & $\begin{array}{l}\text { III. } \begin{array}{l}\text { Masing-masing dalam kelompok mendapatkan wacana/tugas yang berbeda-beda } \\
\text { dan memahami informasi yang ada didalamnya }\end{array} \\
\text { Kelompok }\end{array}$ & I. $\quad$ Mengumpulkan masing-masing tugas siswa yang sama dalam satu kelompok \\
\cline { 2 - 3 } & II. $\begin{array}{l}\text { Guru menugaskan siswa agar belajar bersama untuk menjadi ahli sesuai dengan } \\
\text { wacana/tugas yang menjadi tanggung jawabnya. }\end{array}$ \\
\cline { 2 - 3 } & $\begin{array}{l}\text { III. Guru menugaskan bagi semua anggota kelompok ahli untuk memahami dan } \\
\text { dapat menyampaikan informasi tentang hasil dari tugas yang telah dipahami } \\
\text { kepada kelompok awal. }\end{array}$ \\
\cline { 2 - 3 } & $\begin{array}{l}\text { IV. Apabila tugas sudah selesai dikerjakan dalam kelompok ahli masing-masing } \\
\text { siswa kembali ke kelompok awal. }\end{array}$ \\
\cline { 2 - 3 } & $\begin{array}{l}\text { V. Guru memberikan kesempatan secara bergiliran masing-masing siswa untuk } \\
\text { menyampaikan hasil dari tugas di kelompok ahli }\end{array}$ \\
\cline { 2 - 3 } & $\begin{array}{l}\text { VI. Apabila kelompok sudah menyelesaikan tugasnya, secara keseluruhan masing- } \\
\text { masing kelompok melaporkan hasilnya dan guru memberikan klarifikasi. }\end{array}$ \\
\end{tabular}




\section{Model Pembelajaran Kooperatif Tipe Number Head Together (NHT)}

Dalam model pembelajaran tipe NHT sumbangan penting dari teori Dewey pada langkah (1) penomoran dan langkah (3) berpikir bersama. Pada langkah pertama menekankan pembentukan kelompok-kelompok belajar yang anggotanya heterogen baik tingkat kemampuan, jenis kelamin, ras, dan agama. Pada langkah kedua memberikan motivasi kepada siswa tentang materi yang akan dipelajari. Pada langkah ketiga siswa saling berinteraksi dan bekerja sama dalam mengerjakan tugas-tugas, sedangkan guru membimbing dan memberikan dorongan kepada kelompok-kelompok belajar agar dapat menemukan sendiri pengetahuan yang diperolehnya melalui tugas-tugas yang diberikan.

Teori pendukung selanjutnya adalah teori yang dikemukakan Vygotsky, ada empat prinsip dalam teori Vygotsky yang dikutip (Ratumanan, 2004) sebagai berikut : (1) penekanan pada hakikat sosial budaya belajar adalah menekankan pentingnya peranan lingkungan sosial dan interaksi sosial dalam belajar. Interaksi sosial ini mengacu terbentuknya ide baru dan memerkaya perkembangan intelektual siswa, (2) zona perkembangan terdekat (zone of proximal development), seorang siswa berada dalam zona perkembangan terdekat. Siswa bekerja dalam tugas-tugas yang tidak dapat mereka pecahkan sendiri, tugas tersebut dapat diselesaikan dengan teman sebaya yang lebih mampu. Pada saat siswa bekerja sama, kemungkinan sekali ada tingkat kinerja salah seorang anggota kelompok pada suatu tugas tertentu itu berada pada tingkat kognitif sedikit lebih dari tingkat kinerja siswa lain, 3) pemagangan kognitif (cognitive Apprenticeship), konsep ini mengacu pada proses seseorang yang sedang belajar secara tahap demi tahap memperoleh keahlian interaksinya dengan seseorang pakar. Pakar yang dimaksud di sini adalah orang yang menguasai permasalahan yang dipelajari, jadi dapat berupa orang dewasa atau teman sebaya. Pemagangan dapat dilakukan dengan melibatkan siswa dalam tugas-tugas kelompok heterogen. Dalam kelompok tersebut siswa yang lebih pandai membantu siswa yang kurang pandai dalam menyelesaikan tugas-tugas kelompok tersebut, 4) perancah (scoffolding) pemberian pada seseorang sejumlah besar bantuan, kemudian mengurangi bantuan tersebut dan memberikan kesempatan kepada anak tersebut mengambil alih tanggung jawab yang semakin besar setelah ia dapat melakukannya. Bantuan dapat berupa petunjuk, dorongan, peringatan, menguraikan masalah ke dalam langkah-langkah pemecahan, memberikan contoh, tindakan-tindakan lain yang memungkinkan siswa itu belajar sendiri.

Pembelajaran kooperatif tipe NHT dikembangkan oleh Kagan (1992). Pada umumnya model pembelajaran kooperatif tipe NHT digunakan untuk melibatkan siswa dalam penguatan pemahaman pembelajaran atau mengecek pemahaman siswa terhadap materi pembelajaran. Model pembelajaran kooperatif tipe NHT membawa siswa pada penekanan kognitif dan sosial. Siswa yang mengerjakan tugas yang bersifat sosial dan kognitif ini, akan mengarahkan siswa untuk saling berhubungan dan membagi-bagi situasi. Menurut Piaget (dalam Asri, 2004) bahwa agar seseorang dapat terus mengembangkan dan menambah pengetahuannya sekaligus menjaga stabilitas mental dalam dirinya, maka diperlukan proses penyeimbangan. Proses penyeimbangan yaitu penyeimbangan antara lingkungan luar dengan struktur kognitif yang ada dalam dirinya. Untuk mengoptimalkan manfaat model pembelajaran dengan tipe NHT keanggotaan sebaiknya heterogen baik dari kemampuannya maupun karakteristik lainnya. Jika para siswa yang mempunyai kemampuan berbeda dimasukkan dalam satu kelompok yang sama akan dapat memberi keuntungan bagi para siswa yang berkemampuan rendah dan sedang. Bagi siswa berkemampuan tinggi mendapat kemampuan berkomunikasi verbal yang semakin meningkat.

Pembelajaran kooperatif tipe NHT menurut Kagan (dalam Lie, 2010) akan memberikan kesempatan kepada siswa untuk membagikan ide-ide dan memertimbangkan jawaban yang paling tepat serta mendorong siswa untuk meningkatkan semangat kerja sama mereka.

\section{Hakekat Tipe Kepribadian}

Kepribadian sebagai pola perilaku dan cara berpikir yang khas, yang menentukan penyesuaian diri seseorang terhadap lingkungan. Menurut Hall \& Lindzey (2000) kepribadian adalah sesuatu yang memberikan tata tertib dan keharmonisan terhadap segala macam tingkah laku yang berbeda-beda yang dilakukan oleh individu.

Selanjutnya menurut Alwisol (2004) kepribadian adalah mencakup keseluruhan 
pikiran, perasaan, dan tingkah laku, kesadaran, dan ketidaksadaran. Kepribadian membimbing orang untuk menyesuaikan diri dengan lingkungan sosial dan lingkungan fisik. Kepribadian adalah suatu totalitas terorganisasi dari disposisi-disposisi psikis manusia yang individual yang memberi kemungkinan untuk membedakan ciri-cirinya yang umum dengan pribadi lainnya (Kartono, 2005).

Menurut Djaali (2008) kepribadian adalah kesan yang diberikan seseorang kepada orang lain yang diperoleh dari apa yuang dipikir, dirasakan, dan diperbuat yang terungkap melalui perilaku. Kepribadian merupakan cara yang khas dari individu dalam berperilaku dan merupakan segala sifatnya yang menyebabkan individu yang satu dapat dibedakan dengan individu lain.

Berdasarkan uraian latar belakang masalah dan pembatasan masalah di atas, perumusan masalah sebagai berikut :

1. Apakah hasil belajar PAB kelompok siswa yang diajar dengan menggunakan Model Pembelajaran Kooperatif tipe Jigsaw lebih tinggi dibandingkan dengan menggunakan Model Pembelajaran Kooperatif tipe NHT?

2. Apakah kelompok siswa yang memiliki kepribadian tipe ekstrovert memperoleh hasil belajar PAB lebih tinggi dibandingkan dengan kolompok siswa yang memiliki kepribadian tipe intovert?

3. Apakah terdapat interaksi antara penggunaan model pembelajaran kooperatif dan tipe kepribadian dalam memengaruhi hasil belajar PAB?

\section{METODE}

Penelitian ini dilaksanakan di SMA Swasta Sutomo 1 Medan, Jalan Letkol. Martinus Lubis No. 7 Medan dan SMA Swasta Sutomo 2 Medan. Seluruh populasi diasumsikan memiliki karakteritik yang sama, dimana umur rata-rata siswa tidak berbeda, latar belakang pendidikan guru relatif sama, menggunakan kurikulum yang sama, yaitu berdasarkan Kurikulum Tingkat Satuan Pendidikan (KTSP) 2006. Sampel pada penelitian ini diperoleh secara acak (Cluster Random Sampling). Kelas sampel yang diambil dari SMA Swasta Sutomo 1 adalah kelas X-2 dan dari SMA Swasta Sutomo 2 adalah kelas X1.

Metode yang diterapkan pada penelitian ini adalah metode quasi-eksperimen. Metode ini dipilih karena kelas yang dipakai untuk kelas perlakuan baik kelas pembelajaran dengan menggunakan Model Pembelajaran Kooperatif tipe Jigsaw maupun kelas pembelajaran dengan menggunakan Model Pembelajaran Kooperatif tipe NHT merupakan kelas yang sudah terbentuk sebelumnya dan karakteristik siswa adalah tipe kepribadian.

Desain penelitian yang digunakan adalah desain faktorial $2 \times 2$. Pada penelitian ini terdapat dua faktor yang berpengaruh terhadap hasil belajar PAB yaitu pembelajaran dengan menggunakan model pembelajaran kooperatif dan tipe kepribadian siswa. Variabel-variabel tersebut dapat dilihat pada tabel berikut ini :

Tabel 2. Tabel Desain Penelitian

\begin{tabular}{ccc}
\hline $\begin{array}{c}\text { Tipe } \\
\text { Kepribadian } \\
(\mathbf{B})\end{array}$ & \multicolumn{2}{c}{ Model Pembelajaran (A) } \\
\cline { 2 - 3 } & $\begin{array}{c}\text { Kooperatif } \\
\text { Tipe Jigsaw } \\
\left(\mathrm{A}_{1}\right)\end{array}$ & $\begin{array}{c}\text { kooperatif } \\
\text { Tipe NHT } \\
\left(\mathbf{A}_{2}\right)\end{array}$ \\
\hline $\begin{array}{c}\text { Ekstrovert } \\
\left(\mathbf{B}_{1}\right)\end{array}$ & $\mathrm{A}_{1} \mathrm{~B}_{1}$ & $\mathbf{A}_{2} \mathbf{B}_{1}$ \\
\hline $\begin{array}{c}\text { Introvert } \\
\left(\mathbf{B}_{2}\right)\end{array}$ & $\mathbf{A}_{1} \mathbf{B}_{2}$ & $\mathbf{A}_{2} \mathbf{B}_{2}$ \\
\hline
\end{tabular}

Keterangan :

A : Model Pembelajaran

B : Tipe Kepribadian

$\mathrm{A}_{1} \quad$ : Model Pembelajaran Kooperatif Tipe Jigsaw

$\mathrm{A}_{2} \quad$ : Model Pembelajaran Kooperatif Tipe NHT

$\mathrm{B}_{1} \quad$ : Kepribadian Tipe Ekstrovert

$\mathrm{B}_{2} \quad$ : Kepribadian Tipe Introvert

$\mathrm{A}_{1} \mathrm{~B}_{1}$ : Hasil belajar $\mathrm{PAB}$ yang menggunakan Model Pembelajaran Kooperatif Tipe Jigsaw pada siswa yang memiliki Kepribadian Tipe Ekstrovert

$\mathrm{A}_{1} \mathrm{~B}_{2}$ : Hasil belajar PAB yang menggunakan Model Pembelajaran Kooperatif Tipe Jigsaw pada siswa yang memiliki Kepribadian Tipe Introvert

$\mathrm{A}_{2} \mathrm{~B}_{1}$ : Hasil belajar PAB yang menggunakan Model Pembelajaran Kooperatif Tipe NHT pada siswa yang memiliki Kepribadian Tipe Ekstrovert

$\mathrm{A}_{2} \mathrm{~B}_{2}$ : Hasil belajar PAB yang menggunakan Model Pembelajaran Kooperatif Tipe NHT pada siswa yang memiliki Kepribadian Tipe Introvert

Teknik analisis data yang digunakan untuk pengujian hipotesis adalah analisis varians (ANAVA) dua jalur (two-way Anova). 
Penggunaan teknik ini dimaksudkan agar hasil tes akhir yang dicapai oleh subjek penelitian benar-benar karena pengaruh dari perlakuan yang diberikan dalam proses penelitian dengan taraf signifikansi $\alpha=0,05$. Jika hasil pengujian menunjukkan terdapatnya interaksi maka perlu dilakukan uji lanjut. Dalam penggunaan ANAVA dua jalur harus memenuhi syarat sebagai berikut: (1) data yang digunakan harus berdistribusi normal, sehingga perlu dilakukan uji normalitas dengan menggunakan uji Lillifors, (2) data harus memiliki varians populasi homogen, sehingga dilakukan uji homogenitas varians dengan menggunakan uji Fisher dan uji Bartlet.

Untuk keperluan pengujian hipotesis perlu dirumuskan hipotesis secara statistik yaitu:
1. Ho: $\mu_{\mathrm{A} 1}=\mu_{\mathrm{A} 2}$
Ha: $\mu_{\mathrm{A} 1}>\mu_{\mathrm{A} 2}$
2. Но: $\mu_{\mathrm{B} 1}=\mu_{\mathrm{B} 2}$
$\mathrm{Ha}: \mu_{\mathrm{B} 1}>\mu_{\mathrm{B} 2}$

3. Ho: $\mathrm{A} \times \mathrm{B}=0$

$\mathrm{Ha}: \mathrm{A} \times \mathrm{B} \neq 0$

Keterangan :

$\mu_{\mathrm{A} 1}=$ Hasil belajar PAB siswa yang diajar dengan Model Pembelajran Kooperatif tipe Jigsaw.

$\mu_{\mathrm{A} 2}=$ Hasil belajar PAB siswa yang diajar dengan Model Pembelajran Kooperatif tipe NHT.

$\mu_{\mathrm{B} 1}=$ Hasil belajar $\mathrm{PAB}$ siswa yang memiliki kepribadian tipe ekstrovert.

$\mu_{\mathrm{B} 2}=$ Hasil belajar $\mathrm{PAB}$ siswa yang memiliki kepribadian tipe introvert.

$\mathrm{A} \times \mathrm{B}=$ Interaksi antara penggunaan Model Pembelajran Kooperatif tipe Jigsaw dengan kepribadian tipe ekstrovert.

\section{HASIL PENELITIAN}

Analisis data hasil penelitian secara deskripsi ditampilkan pada tabel berikut :

Tabel 3. Deskripsi Data Hasil Penelitian

\begin{tabular}{|c|c|c|c|c|c|c|}
\hline \multirow{2}{*}{$\begin{array}{l}\text { Tipe Kepribadian } \\
\text { ( B ) }\end{array}$} & \multicolumn{4}{|c|}{ Model Pembelajaran Kooperatif } & \multirow{2}{*}{\multicolumn{2}{|c|}{ Total }} \\
\hline & \multicolumn{2}{|c|}{ Jigsaw $\left(\mathbf{A}_{1}\right)$} & \multicolumn{2}{|c|}{$\operatorname{NHT}\left(A_{2}\right)$} & & \\
\hline \multirow{5}{*}{$\begin{array}{c}\text { Ekstrovert } \\
\left(\mathbf{B}_{1}\right)\end{array}$} & $\mathrm{n}_{\mathrm{A} 1 \mathrm{~B} 1}$ & 22 & $\mathrm{n}_{\mathrm{A} 2 \mathrm{~B} 1}$ & 20 & $\mathrm{n}_{\mathrm{t}}$ & 42 \\
\hline & $\bar{X}_{\mathrm{A} 1 \mathrm{~B} 1}$ & 34.864 & $\bar{X}_{\mathrm{A} 2 \mathrm{~B} 1}$ & 30.100 & $\overline{\bar{X}}_{\mathrm{t}}$ & 32.595 \\
\hline & SD & 2.517 & SD & 2.563 & SD & 3.477 \\
\hline & $\Sigma \mathrm{X}$ & 768 & $\Sigma X$ & 601 & $\Sigma \mathrm{X}$ & 1369 \\
\hline & $\Sigma X^{2}$ & 26936 & $\Sigma \mathrm{X}^{2}$ & 18173 & $\Sigma X^{2}$ & 45109 \\
\hline \multirow{5}{*}{$\begin{array}{c}\text { Introvert } \\
\left(\mathbf{B}_{2}\right)\end{array}$} & $\mathrm{n}_{\mathrm{A} 1 \mathrm{~B} 2}$ & 18 & $\mathrm{n}_{\mathrm{A} 2 \mathrm{~B} 2}$ & 20 & $\mathrm{n}_{\mathrm{t}}$ & 38 \\
\hline & $\bar{X}_{\mathrm{A} 1 \mathrm{~B} 2}$ & 30.278 & $\bar{X}_{\mathrm{A} 2 \mathrm{~B} 2}$ & 32.600 & $\bar{X}_{\mathrm{t}}$ & 31.395 \\
\hline & SD & 2.557 & SD & 2.634 & SD & 3.012 \\
\hline & $\Sigma \mathrm{X}$ & 543 & $\Sigma X$ & 652 & $\Sigma \mathrm{X}$ & 1195 \\
\hline & $\Sigma \mathrm{X}^{2}$ & 16499 & $\Sigma \mathrm{X}^{2}$ & 21386 & $\Sigma \mathrm{X}^{2}$ & 37885 \\
\hline \multirow[t]{5}{*}{ Total } & $\mathrm{n}_{\mathrm{t}}$ & 40 & $\mathrm{n}_{\mathrm{t}}$ & 40 & $\mathrm{n}_{\mathrm{tot}}$ & 80 \\
\hline & $\bar{X}$ & 32.800 & $\bar{X}$ & 31.300 & $\bar{X}_{\mathrm{Tot}}$ & 32.075 \\
\hline & SD & 3.406 & SD & 2.857 & SD & 3.209 \\
\hline & $\Sigma \mathrm{X}$ & 1311 & $\Sigma X$ & 1253 & $\Sigma \mathrm{X}$ & 2564 \\
\hline & $\Sigma X^{2}$ & 43435 & $\Sigma X^{2}$ & 39559 & $\Sigma \mathrm{X}^{2}$ & 82994 \\
\hline
\end{tabular}

Pengujian hipotesis dilakukan menggunakan tehnik analisis varians (ANAVA). Untuk keperluaan analisis varians, data yang diperlukan dapat dilihat pada tabel berikut.

Tabel 4. Rangkuman Analisis Faktorial 2x2

\begin{tabular}{lrcrrrc}
\hline \multicolumn{1}{c}{ Sumber Varians } & JK & Dk & \multicolumn{1}{c}{ RJK } & $\mathbf{F}_{\text {hitung }}$ & $\mathbf{F}_{\text {tabel }}$ & Kesimpulan \\
\hline Model Pembelajaran & 42.050 & 1 & 42.050 & 6.548 & 3.96 & Signifikan \\
\hline Tipe Kepribadian & 26.286 & 1 & 26.286 & 4.093 & 3.96 & Signifikan \\
\hline Interaksi & 261.396 & 1 & 261.396 & 40.703 & 3.96 & Signifikan \\
\hline Antar kelompok & 329.732 & 3 & & & & \\
\hline Dalam kelompok & 488.068 & 76 & & & & \\
\hline Total & 817.800 & 79 & & & & \\
\hline
\end{tabular}


Berdasarkan rangkuman pada tabel tersebut, maka akan dirinci pengujian hipotesis sebagai berikut:

\section{Hipotesis Pertama}

Pengujian hipotesis pertama yang menyatakan hasil belajar PAB siswa yang dibelajarkan dengan Model Pembelajaran Kooperatif tipe Jigsaw, lebih tinggi daripada hasil belajar siswa yang diajarkan dengan Model Pembelajaran Kooperatif tipe NHT, hipotesis statistiknya adalah :

$$
\text { Ho }: \mu_{\mathrm{A} 1}=\mu_{\mathrm{A} 2} \quad \text { Ha }: \mu_{\mathrm{A} 1}>\mu_{\mathrm{A} 2}
$$

Pernyataan hipotesis tersebut adalah :

Ho = Rata-rata hasil belajar PAB siswa yang dibelajarkan dengan menggunakan

Model Pembelajaran Kooperatif tipe Jigsaw lebih kecil atau sama dengan rata rata hasil belajar PAB siswa yang dibelajarkan dengan Model Pembelajaran Kooperatif tipe NHT.

$\mathrm{Ha}=$ Siswa yang dibelajarkan dengan menggunakan Model Pembelajaran Kooperatif tipe Jigsaw memperoleh rata-rata hasil belajar PAB lebih tinggi dari pada siswa yang dibelajarkan dengan Model Pembelajaran Kooperatif tipe NHT.

Berdasarkan perhitungan ANAVA faktorial $2 \times 2$ diperoleh $F_{\text {hitung }}=6.548$ sedangkan nilai $\mathrm{F}_{\text {tabel }}=3.96$ untuk dk $(1,76)$ dan taraf nyata $\alpha=0,05$. Ternyata nilai $F_{\text {hitung }}=6.548>\mathrm{F}_{\text {tabel }}=$ 3.96, pengujian hipotesis menolak Ho dan menerima $\mathrm{Ha}$, sehingga ditarik kesimpulan bahwa hasil belajar PAB siswa yang dibelajarkan dengan Model Pembelajaran Kooperatif tipe Jigsaw lebih tinggi dibandingkan dengan Model Pembelajaran Kooperatif tipe NHT teruji kebenarannya secara empirik. Hal ini juga terlihat dari rata-rata hasil belajar PAB yang dibelajarkan dengan Model Pembelajaran Kooperatif tipe Jigsaw $(\bar{X}=$ 32.800 ) lebih tinggi dari hasil belajar PAB yang dibelajarkan dengan Model Pembelajaran Kooperatif tipe NHT $(\bar{X}=31.300)$.

\section{Hipotesis Kedua}

Pengujian hipotesis kedua yang menyatakan : hasil belajar PAB siswa yang memiliki kepribadian tipe ekstrovert, lebih tinggi daripada hasil belajar PAB siswa yang memiliki kepribadian tipe introvert, hipotesis statistiknya adalah:
Ho : $\mu_{\mathrm{B} 1}=\mu_{\mathrm{B} 2} \quad$ Ha : $\mu_{\mathrm{B} 1}>$ $\mu_{\mathrm{B} 2}$ Pernyataan hipotesis tersebut adalah :

Ho = Siswa yang memiliki kepribadian tipe ekstrovert memperoleh rata-rata hasil belajar PAB lebih rendah atau sama dengan siswa yang memiliki kepribadian tipe introvert.

$\mathrm{Ha}=$ Siswa yang memiliki kepribadian tipe ekstrovert memperoleh hasil belajar PAB lebih tinggi daripada siswa yang memiliki kepribadian tipe introvert.

Berdasarkan perhitungan ANAVA faktorial $2 \times 2$ diperoleh $\mathrm{F}_{\text {hitung }}=4.093$ sedangkan nilai $\mathrm{F}_{\text {tabel }}=3.96$ untuk dk $(1,76)$ dan taraf nyata $\alpha=0,05$. Ternyata nilai $F_{\text {hitung }}=4.093>F_{\text {tabel }}=$ 3.96, pengujian hipotesis menolak Ho dan menerima $\mathrm{Ha}$, sehingga ditarik kesimpulan bahwa hasil belajar PAB siswa yang memiliki kepribadian tipe ekstrovert lebih tinggi dibanding siswa yang memiliki kepribadian tipe introvert teruji kebenarannya secara empirik. Hal ini juga terlihat dari rata-rata hasil belajar PAB yang memiliki kepribadian tipe ekstrovert $(\bar{X}=32.595)$ lebih tinggi dari hasil belajar PAB siswa yang memiliki kepribadian tipe introvert $(\bar{X}=31.395)$.

\section{Hipotesis Ketiga}

Pengujian hipotesis yang ketiga yaitu: terdapat interaksi antara model pembelajaran kooperatif dan tipe kepribadian dalam meningkatkan hasil belajar PAB.

$$
\text { Ho : A X B }=0 \quad \text { Ha : A X B } \neq 0
$$

Pernyataan hipotesis tersebut adalah :

Ho = Tidak terdapat interaksi antara model pembelajaran kooperatif dan tipe kepribadian terhadap hasil belajar PAB siswa.

$\mathrm{Ha}=$ Terdapat interaksi antara model pembelajaran kooperatif dan tipe kepribadian terhadap hasil belajar $\mathrm{PAB}$ siswa.

Berdasarkan perhitungan ANAVA faktorial $2 \times 2$ diperoleh $F_{\text {hitung }}=40.70$ sedangkan nilai $\mathrm{F}_{\text {tabel }}=3.96$ untuk dk $(1,76)$ dan taraf nyata $\alpha=0,05$. Ternyata nilai $F_{\text {hitung }}=40.70>F_{\text {tabel }}=$ 3.96, pengujian hipotesis menolak Ho dan menerima $\mathrm{Ha}$, sehingga ditarik kesimpulan bahwa terdapat interaksi antara model pembelajaran kooperatif dan tipe kepribadian terhadap hasil belajar PAB siswa, teruji kebenarannya secara empirik. 
Untuk melihat perbandingan kombinasi interaksi antara model pembelajaran kooperatif dan tipe kepribadian terhadap hasil belajar $\mathrm{PAB}$, maka dilakukan uji lanjut dengan Uji Scheffe. Perhitungan untuk uji Scheffe. Rangkuman hasil perhitungan uji Scheffe dapat dilihat pada tabel berikut :

Tabel 23. Rangkuman Hasil Uji Scheffe

\begin{tabular}{|c|c|c|c|}
\hline \multicolumn{2}{|c|}{ Hipotesis Statistik } & \multirow{2}{*}{$\begin{array}{c}\mathbf{F}_{\text {hitung }} \\
7.77\end{array}$} & \multirow{2}{*}{$\begin{array}{c}\mathbf{F}_{\text {tabel }} \\
(\mathbf{3 , 7 6}) \\
\boldsymbol{\alpha}= \\
\mathbf{0 , 0 5} \\
2.72\end{array}$} \\
\hline $\begin{array}{c}\text { Ho: } \mu_{\mathrm{A} 1 \mathrm{~B} 1}= \\
\mu_{\mathrm{A} 2 \mathrm{~B} 1}\end{array}$ & $\begin{array}{c}\mathrm{Ha}: \mu_{\mathrm{A} 1 \mathrm{~B} 1}> \\
\mu_{\mathrm{A} 2 \mathrm{~B} 1}\end{array}$ & & \\
\hline $\begin{array}{c}\text { Ho: } \mu_{\mathrm{A} 1 \mathrm{~B} 1}= \\
\mu_{\mathrm{A} 1 \mathrm{~B} 2}\end{array}$ & $\begin{array}{c}\mathrm{Ha}: \mu_{\mathrm{A} 1 \mathrm{~B} 1}> \\
\mu_{\mathrm{A} 1 \mathrm{~B} 2}\end{array}$ & 7.07 & 2.72 \\
\hline $\begin{array}{c}\text { Ho: } \mu_{\mathrm{A} 1 \mathrm{~B} 1}= \\
\mu_{\mathrm{A} 2 \mathrm{~B} 2}\end{array}$ & $\begin{array}{c}\mathrm{Ha}: \mu_{\mathrm{A} 1 \mathrm{~B} 1}> \\
\mu_{\mathrm{A} 2 \mathrm{~B} 2}\end{array}$ & 3.69 & 2.72 \\
\hline $\begin{array}{c}\text { Ho: } \mu_{\mathrm{A} 2 \mathrm{~B} 1}= \\
\mu_{\mathrm{A} 1 \mathrm{~B} 2}\end{array}$ & $\begin{array}{c}\mathrm{Ha}: \mu_{\mathrm{A} 2 \mathrm{~B} 1}< \\
\mu_{\mathrm{A} 1 \mathrm{~B} 2}\end{array}$ & 0.26 & 2.72 \\
\hline $\begin{array}{c}\text { Ho: } \mu_{\mathrm{A} 2 \mathrm{~B} 2}= \\
\mu_{\mathrm{A} 2 \mathrm{~B} 2}\end{array}$ & $\begin{array}{c}\mathrm{Ha}: \mu_{\mathrm{A} 2 \mathrm{~B} 1}> \\
\mu_{\mathrm{A} 2 \mathrm{~B} 2}\end{array}$ & 3.89 & 2.72 \\
\hline $\begin{array}{c}\text { Ho: } \mu_{\mathrm{A} 2 \mathrm{~B} 1}= \\
\mu_{\mathrm{A} 2 \mathrm{~B} 2}\end{array}$ & $\begin{array}{c}\mathrm{Ha}: \mu_{\mathrm{A} 2 \mathrm{~B} 2}> \\
\mu_{\mathrm{A} 1 \mathrm{~B} 2}\end{array}$ & 3.43 & 2.72 \\
\hline
\end{tabular}

Berdasarkan tabel tersebut, terdapat satu dari enam kombinasi yang dibandingkan menunjukkan hasil yang tidak signifikan, hal ini disebabkan oleh tidak terdapatnya perbedaan yang signifikan antara rata-rata hasil belajar PAB dalam sel. Dari hasil uji Scheffe diperoleh simpulan:

(1) Rata-rata hasil belajar PAB siswa yang dibelajarkan dengan Model Pembelajaran Kooperatif tipe Jigsaw berdasarkan kepribadian tipe ekstrovert lebih tinggi dibandingkan dengan rata-rata hasil belajar PAB siswa yang dibelajarkan dengan Model Pembelajaran Kooperatif tipe NHT berdasarkan kepribadian tipe introvert.

(2) Rata-rata hasil belajar PAB siswa yang dibelajarkan dengan Model Pembelajaran Kooperatif tipe Jigsaw berdasarkan kepribadian tipe ekstrovert lebih tinggi dibanding dengan rata-rata hasil belajar PAB siswa dengan Model Pembelajaran Kooperatif tipe Jigsaw berdasarkan kepribadian tipe introvert.

(3) Rata-rata hasil belajar PAB siswa yang dibelajarkan dengan Model Pembelajaran Kooperatif tipe Jigsaw berdasarkan kepribadian tipe ekstrovert lebih tinggi dibandingkan dengan rata-rata hasil belajar
PAB siswa yang dibelajarkan dengan Model Pembelajaran Kooperatif tipe NHT berdasarkan kepribadian tipe introvert.

(4) Rata-rata hasil belajar PAB siswa yang dibelajarkan dengan Model Pembelajaran Kooperatif tipe Jigsaw berdasarkan kepribadian tipe introvert lebih rendah dibanding dengan rata-rata hasil belajar PAB siswa yang dibelajarkan dengan Model Pembelajaran Kooperatif tipe NHT berdasarkan kepribadian tipe ekstrovert.

(5) Rata-rata hasil belajar PAB siswa yang dibelajarkan dengan Model Pembelajaran Kooperatif tipe NHT berdasarkan kepribadian tipe ekstrovert lebih tinggi dibandingkan dengan rata-rata hasil belajar PAB siswa yang dibelajarkan dengan Model Pembelajaran Kooperatif tipe NHT berdasarkan kepribadian tipe introvert.

(6) Rata-rata hasil belajar PAB siswa dengan Model Pembelajaran Kooperatif tipe Jigsaw berdasarkan kepribadian tipe introvert lebih tinggi dibandingkan dengan rata-rata hasil belajar $\mathrm{PAB}$ siswa dengan Model Pembelajaran Kooperatif tipe NHT berdasarkan kepribadian tipe introvert.

Hasil pengujian lanjut, menunjukkan adanya interaksi antara model pembelajaran kooperatif dan tipe kepribadian terhadap hasil belajar PAB siswa SMA Swasta Sutomo 1 dan 2 Medan.

Interaksi model pembelajaran kooperatif dan tipe kepribadian dapat ditunjukkan seperti pada gambar berikut ini :

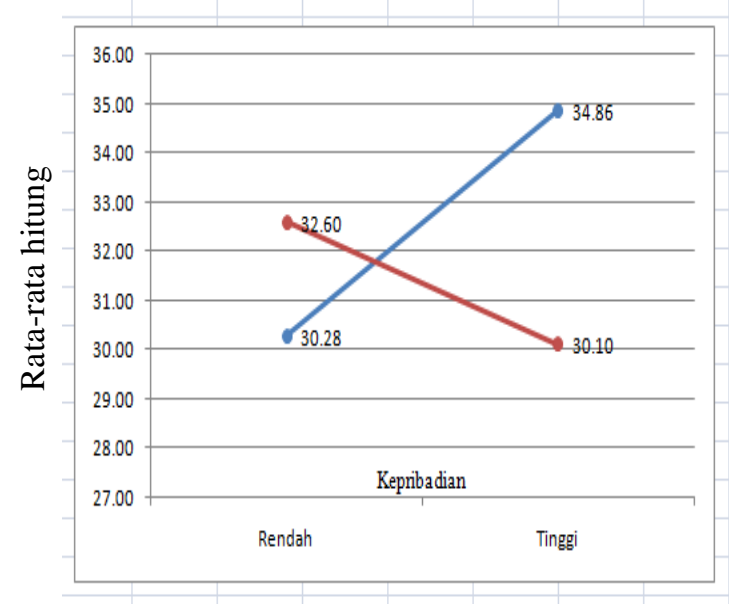

Gambar 1. Interaksi Antara Pembelajaran dengan Menggunakan Model Pembelajaran Kooperatif dan Tipe Kepribadian Terhadap Hasil Belajar PAB 
Berdasarkan hasil pengujian hipotesis ketiga yang menyatakan adanya interaksi antara model pembelajaran kooperatif dengan tipe kepribadian, maka perlu dilakukan uji perbedaan rata-rata antara dua proposi. Gambar tersebut menunjukkan pengaruh dan interaksi dari model pembelajaran kooperatif dan tipe kepribadian terhadap hasil belajar PAB yang diperoleh siswa, rata-rata hasil belajar $\mathrm{PAB}$ yang dibelajarkan dengan Model Pembelajaran Kooperatif tipe Jigsaw lebih tinggi dibandingkan dengan Model Pembelajaran Kooperatif tipe NHT. Penelitian ini juga membuktikan faktor tipe kepribadian sebagai salah satu karakteristik siswa perlu diperhatikan karena terbukti bahwa tipe kepribadian siswa berpengaruh terhadap hasil belajar PAB.

\section{PEMBAHASAN}

1. Perbedaan Hasil Belajar PAB Antara Siswa yang Dibelajarkan dengan Menggunakan Model Pembelajaran Kooperatif Tipe Jigsaw dan Siswa yang Dibelajarkan dengan Menggunakan Model Pembelajaran Kooperatif Tipe NHT

Dari hasil pengolahan data penelitian yang dilakukan, terdapat perbedaan hasil belajar PAB antara siswa yang dibelajarkan dengan menggunakan Model Pembelajaran Kooperatif tipe Jigsaw dan siswa yang dibelajarkan dengan menggunakan Model Pembelajaran Kooperatif tipe NHT, yaitu rata-rata hasil belajar $\mathrm{PAB}$ siswa yang dibelajarkan dengan menggunakan Model Pembelajaran Kooperatif tipe Jigsaw lebih tinggi dibandingkan dengan siswa yang dibelajarkan dengan menggunakan Model Pembelajaran Kooperatif tipe NHT. Dari data ini membuktikan bahwa penggunaan Model Pembelajaran Kooperatif tipe Jigsaw lebih baik dalam meningkatkan pengetahuan siswa dalam pembelajaran PAB daripada penggunaan Model Pembelajaran Kooperatif tipe NHT. Ini beralasan, karena Model Pembelajaran Kooperatif tipe Jigsaw banyak melakukan diskusi, presentasi, tanya jawab yang dapat meningkatkan pemahaman siswa dalam memelajari PAB. Jika Model Pembelajaran Kooperatif tipe Jigsaw ini diterapkan pada pembelajaran PAB diyakini akan dapat memberikan pengaruh terhadap hasil belajar siswa. Hal ini akan terjadi karena dalam kegiatan pembelajaran $\mathrm{PAB}$ dibutuhkan kemampuan berpikir, menemukan ide, memberikan saran, dan gagasan terhadap setiap materi yang akan dipelajari. Dalam Model
Pembelajaran Kooperatif tipe Jigsaw, siswa akan melakukan pergantian anggota kelompok dalam bentuk kelompok asal dan kelompok ahli, sehingga siswa mempunyai kesempatan untuk berinteraksi dengan siswa kelompok lain. Hal yang dikemukakan seperti pendapat Lie (2010) menjelaskan bahwa pembelajaran kooperatif adalah sistem pembelajaran yang memberikan kesempatan kepada siswa untuk bekerja sama dengan sesama siswa dalam tugas-tugas terstruktur. Selanjutnya menurut Slavin (1995) bahwa dalam pembelajaran kooperatif, siswa bekerja sama dalam kelompok kecil, saling membantu untuk memelajari materi. Artinya aktivitas belajar oleh kelompok kecil siswa yang di dalamnya terjadi kerja sama, saling menyumbangkan pikiran untuk menyelesaikan tugas-tugas kelompok, pemecahan masalah, dan bertanggung jawab terhadap pencapaian hasil belajar secara individu maupun kelompok.

Secara psikologis Model Pembelajaran Kooperatif tipe Jigsaw ini memberikan manfaat yang sangat besar terhadap siswa antara lain : (1) memotivasi siswa untuk belajar giat karena adanya tekanan teman kelompoknya seta menyadari akan penilaian yang berkelanjutan, (2) menghilangkan rasa takut pada anak untuk mengungkapkan pendapatnya dan menjawab pertanyaan, dan (3) menumbuhkan kemampuan kerja sama siswa berpikir kritis dan kemampuan membantu teman. Hal tersebut sesuai dengan pendapat Slavin (1995) mengemukakan beberapa tujuan khusus Model Pembelajaran Kooperatif tipe Jigsaw diantaranya adalah penghargaan kelompok, pertanggungjawaban individu dan kesempatan yang sama untuk berhasil.

Hal tersebut tersebut berbeda dengan pembelajaran menggunakan Model Pembelajaran Kooperatif tipe NHT, yang pada dasarnya merupakan sebuah varian diskusi kelompok, ciri khasnya adalah hanya menunjuk seorang siswa yang memiliki kelompoknya, tanpa memberi tahu terlebih dahulu siapa yang akan mewakili kelompok itu. Cara ini menjamin keterlibatan total semua siswa. Model Pembelajaran Kooperatif tipe NHT merupakan diantara bentuk-bentuk pembelajaran kooperatif yang paling tua dan luas digunakan ini berupa diskusi kelompok dan proyek kelompok, dimana kelompok-kelompok diskusi tersebut memastikan setiap anggota berperan serta dalam kegiatan kelompok tidak didominasi oleh seorang anggota saja, setiap 
kelompok memilih seorang pemimpin yang mampu mengorganisasikan kelompok mereka, proyek-proyek kelompok yang baik adalah sama dengan prinsip dari diskusi yang baik, setiap kelompok menulis laporan yang diinginkan oleh guru. Kagen (1992) telah mendeskripsikan hanya struktur informal untuk pengembangan pembelajaran kooperatif yang dapat diterapkan dalam pelajaran sehari-hari, salah satunya yakni dengan menggunakan Model Pembelajaran Kooperatif tipe NHT.

Dari penjelasan tersebut, dapat dipahami bahwa hasil belajar PAB siswa yang diajar dengan Model Pembelajaran Kooperatif tipe Jigsaw lebih tinggi daripada siswa yang dibelajarkan dengan Model Pembelajarn Kooperatif tipe NHT.

2. Perbedaan Hasil Belajar PAB Antara Siswa yang Memiliki Kepribadian Tipe Ekstovert dan Siswa yang Memiliki Kepribadian Tipe Introvert

Dari hasil penelitian ini, juga menunjukkan bahwa rata-rata hasil belajar PAB siswa yang memiliki kepribadian tipe ekstrovert lebih tinggi daripada hasil belajar PAB siswa yang memiliki kepribadian tipe introvert. Hal ini mengindikasikan bahwa siswa yang memiliki kepribadian tipe ekstovert lebih mampu memahami pelajaran $\mathrm{PAB}$ dibandingkan dengan siswa yang memiliki kepribadian tipe introvert. Hal ini beralasan, karena siswa yang memiliki kepribadian tipe ekstrovert memiliki karakteristik mampu berinteraksi dengan teman, guru atau orang lain dengan lebih baik. Mereka memiliki kemampuan memengaruhi teman belajarnya, lebih menonjol dalam kerja kelompok karena kecenderungannya yang suka bersosialisasi. Mereka menyenangi bekerja sama dengan orang lain, tidak merasa terpaksa untuk bersama orang lain, tidak merasa kaku untuk berbicara di depan umum yang belum dikenal, mudah bergaul, dan menyenangi bertemu dengan orang-orang yang baru. Selain itu, siswa yang memiliki kepribadian tipe ekstrovert memiliki kemampuan berkomunikasi yang baik, cakap membina hubungan sosial maupun mengadakan interaksi dengan teman-temannya baik di dalam kelas maupun di dalam kelompok mereka, sehingga sangat cocok dan merasa nyaman dengan model pembelajaran kooperatif yang diterapkan.

Sedangkan kepribadian tipe introvert adalah siswa yang cenderung pendiam, lebih senang sendirian, dan tidak terlalu menyukai situasi yang mengharuskannya berinteraksi dengan orang lain. Siswa dengan tipe kepribadian ini mudah tersinggung, kurang percaya diri, pemalu, dan pendiam. Mereka biasanya hidup dengan dunia yang penuh dengan fantasi, impian, dan persepsi individualis, memiliki nilai estetika yang tinggi, dan suka aktivitas yang bersifat artistik. Mereka lebih senang belajar sendirian daripada belajar berkelompok, tidak cakap bersosialisasi, cenderung sebagai pengikut, dan tidak aktif berdiskusi sehingga akan kesulitan jika harus belajar berkelompok.

Dengan demikian, keadaan ini sesuai dengan penelitian yang dilakukan oleh Kesmapuri (2006) yang menunjukkan dalam penelitiannya bahwa remaja yang berkepribadian tipe ekstrovert memiliki motif sosial yang lebih tinggi bila dibandingkan dengan remaja yang berkepribadian tipe introvert.

3. Interaksi Antara Model Pembelajaran Koopertif dan Tipe Kepribadian Terhadap Hasil Belajar PAB

Temuan penelitian menunjukkan bahwa terdapat interaksi antara model pembelajaran kooperatif dan tipe kepribadian terhadap hasil belajar PAB siswa yang memiliki kepribadian tipe ekstrovert yang dibelajarkan dengan Model Pembelajaran Kooperatif tipe Jigsaw memeroleh hasil belajar PAB yang lebih tinggi daripada siswa yang memiliki kepribadian tipe ekstrovert yang dibelajarkan dengan menggunakan Model Pembelajaran Kooperatif tipe NHT. Demikian pula siswa yang memiliki kepribadian tipe introvert yang dibelajarkan dengan menggunakan Model Pembelajaran Kooperatif tipe Jigsaw memeroleh hasil belajar $\mathrm{PAB}$ yang lebih rendah dibandingkan dengan siswa yang dibelajarkan dengan menggunakan Model Pembelajaran Kooperatif tipe NHT, meskipun dalam penelitian ini tidak terdapat perbedaan yang signifikan. Hal ini mengindikasikan adanya interaksi antara penggunaan model pembelajaran kooperatif dengan tipe kepribadian terhadap hasil belajar $\mathrm{PAB}$ siswa.

Model pembelajaran kooperatif menurut Arend (2008) ada tiga tujuan yang diharapkan dapat dicapai, yaitu : (1) prestasi akademik, pembelajaran kooperatif sangat menguntungkan baik bagi siswa berkemampuan tinggi maupun rendah, khususnya bagi siswa 
berkemampuan tinggi, secara akademik akan mendapat keuntungan karena pengetahuan semakin mendalam, (2) penerimaan terhadap keragaman, pembelajaran kooperatif memberikan kesempatan siswa dengan latar belakang dan kondisi yang beragam untuk bekerja secara interdependen pada tugas yang sama dan belajar untuk saling menghargai, (3) pengembangan keterampilan sosial, pembelajaran kooperatif bertujuan mengarahkan kepada keterampilanketerampilan kerjasama sebagai suatu tim. Jika dihubungkan dengan model pembelajaran kooperatif, kepribadian tipe ekstrovert cenderung lebih diuntungkan karena akan terlihat lebih aktif dalam pembelajaran kooperatif, kepribadiannya yang suka berbicara dan berinteraksi dengan orang lain sesuai dengan pembelajaran kooperatif yang menuntut banyak interaksi dan partisipasi siswa. Seperti yang dikemukakan oleh Jung (dalam Djaali, 2008) bahwa kepribadian individu dapat dibedakan antara dua sisi introvert dan ekstrovert. Pada diri individu yang introvert umumnya memiliki sifat-sifat cenderung menarik diri, suka bekerja sendiri, tenang, pemalu, hati-hati dalam mengambil keputusan dan cenderung tertutup secara sosial. Individu yang ekstrovert pada umumnya memiliki ciriciri suka berpandangan atau berorientasi keluar, bebas, dan terbuka secara sosial, sigap, dan tidak sabar dalam menghadapi yang lamban dan suka bekerja kelompok.

Dalam pembelajaran kooperatif tipe NHT, siswa dengan kepribadian tipe ekstrovert juga cenderung diuntungkan karena masih berhubungan dengan banyaknya interaksi dan diskusi kelas. Namun dalam Pembelajaran Kooperatif tipe NHT, aktivitas siswa tidak terlalu banyak hanya berdiskusi dengan teman satu kelompok. Dalam hal ini, siswa dengan kepribadian tipe ekstrovert terlihat aktif namun tidak maksimal. Sebaliknya, siswa dengan kepribadian tipe introvert cenderung nyaman dengan kondisi Pembelajaran Kooperatif tipe NHT dibandingkan dengan Pembelajaran Kooperatif tipe Jigsaw. Dalam Pembelajaran Kooperatif tipe NHT, siswa dengan kepribadian tipe introvert merasa nyaman karena diskusi hanya terjadi dalam satu kelompok, siswa tidak dituntut melakukan presentasi di depan kelas dan hanya menjawab pertanyaan guru seandainya nomornya disebut.

Melihat perbedaan-perbedaan pokok dalam kegiatan Model Pembelajaran Kooperatif tipe Jigsaw dan tipe NHT serta perbedaan karakteristik kepribadian tipe ekstrovert dan tipe introvert sebagaimana telah dijelaskan pada pembahasan sebelumnya, maka dapat dipahami bahwa Model Pembelajaran Kooperatif tipe Jigsaw akan lebih efektif untuk meningkatkan hasil belajar PAB dibandingkan dengan Model Pembelajaran Kooperatif tipe NHT. Seperti pendapat Isjoni (2010) yang mengemukakan bahwa Pembelajaran Kooperatif tipe Jigsaw merupakan salah satu tipe pembelajaran kooperatif yang mendorong siswa aktif dan saling membantu dalam menguasai materi pelajaran untuk mencapai prestasi yang maksimal.

Dengan demikian, dapat dipahami bahwa siswa dengan kepribadian tipe ekstrovert akan memeroleh nilai hasil belajar yang lebih tinggi jika diajar dengan Model Pembelajaran Kooperatif tipe Jigsaw. Sebaliknya siswa dengan kepribadian tipe introvert akan memeroleh nilai hasil belajar yang lebih tinggi, jika diajar dengan Model Pembelajaran Kooperatif tipe NHT. Jadi interaksi model pembelajaran kooperatif dan tipe kepribadian dapat meningkatkan kemampuan siswa dalam memeroleh hasil belajar PAB yang lebih baik.

Uji lanjut dengan uji Scheffe dimana terdapat interaksi yang ditunjukkan nilai hasil belajar PAB siswa dengan menggunakan Model Pembelajaran Kooperatif dan tipe kepribadian, yaitu :

1. Hasil belajar PAB siswa yang dibelajarkan dengan Model Pembelajaran Kooperatif tipe Jigsaw pada siswa yang memiliki kepribadian tipe ekstrovert lebih tinggi dengan hasil belajar PAB siswa dengan menggunakan Model Pembelajaran Kooperatif tipe NHT pada siswa yang memiliki kepribadian tipe ekstrovert.

2. Hasil belajar PAB siswa yang dibelajarkan dengan Model Pembelajaran Kooperatif tipe Jigsaw pada siswa yang memiliki kepribadian tipe ekstrovert lebih tinggi dengan hasil belajar PAB siswa dengan menggunakan Model Pembelajaran Kooperatif tipe Jigsaw pada siswa yang memiliki kepribadian tipe introvert.

3. Hasil belajar PAB siswa yang dibelajarkan dengan Model Pembelajaran Kooperatif tipe Jigsaw pada siswa yang memiliki kepribadian tipe ekstrovert lebih tinggi dengan hasil belajar PAB siswa dengan menggunakan Model Pembelajaran 
Kooperatif tipe NHT pada siswa yang memiliki kepribadian tipe introvert.

4. Hasil belajar PAB siswa dengan menggunakan Model Pembelajaran Kooperatif tipe NHT pada siswa yang memiliki kepribadian tipe ekstrovert lebih rendah dengan hasil belajar PAB siswa dengan menggunakan Model Pembelajaran Kooperatif tipe Jigsaw pada siswa yang memiliki kepribadian tipe introvert.

5. Hasil belajar PAB siswa dengan menggunakan Model Pembelajaran Kooperatif tipe NHT pada siswa yang memiliki kepribadian tipe ekstrovert lebih tinggi dengan hasil belajar PAB siswa dengan menggunakan Model Pembelajaran Kooperatif tipe NHT pada siswa yang memiliki kepribadian tipe introvert.

6. Hasil belajar PAB siswa dengan menggunakan Model Pembelajaran Kooperatif tipe NHT pada siswa yang memiliki kepribadian tipe introvert lebih tinggi dengan hasil belajar PAB siswa dengan menggunakan Model Pembelajaran Kooperatif tipe Jigsaw pada siswa yang memiliki kepribadian tipe introvert.

\section{PENUTUP}

Berdasarkan hasil penelitian dan pembahasan yang dikemukakan sebelumnya, maka dalam penelitian ini dapat disimpulkan bahwa :

1. Penggunaan Model Pembelajaran Kooperatif tipe Jigsaw memberikan pengaruh terhadap hasil belajar PAB yang lebih tinggi bila dibandingkan dengan penggunaan Model Pembelajaran Kooperatif tipe NHT.

2. Hasil belajar PAB siswa yang memiliki kepribadian tipe ekstrovert lebih tinggi daripada hasil belajar PAB siswa yang memiliki kepribadian tipe introvert.

3. Terdapat interaksi antara penggunaan Model Pembelajaran Kooperatif tipe Jigsaw dan tipe kepribadian dalam memengaruhi hasil belajar PAB siswa. Hal ini terbukti dari hasil uji lanjutan yang memberikan kesimpulan bahwa kelompok siswa yang memiliki kepribadian tipe ekstrovert memeroleh hasil belajar PAB lebih tinggi jika dibelajarkan dengan menggunakan Model Pembelajaran Kooperatif tipe Jigsaw daripada menggunakan Model Pembelajaran Kooperatif tipe NHT.
Berdasarkan nilai rata-rata yang diperoleh diketahui bahwa untuk siswa yang memiliki kepribadian tipe ekstrovert akan lebih efektif dalam meningkatkan hasil belajar PAB jika menggunakan Model Pembelajaran Kooperatif tipe Jigsaw, sedangkan untuk siswa yang memiliki kepribadian tipe introvert lebih efektif dalam meningkatkan hasil belajar $\mathrm{PAB}$ dengan menggunakan Model Pembelajaran Kooperatif tipe NHT.

\section{DAFTAR PUSTAKA}

Alwisol. (2004). Psikologi Kepribadian. Malang: UMM Press.

Anderson, O. W. Krathwohl. (2001). A Taxonomy for Learning, Teaching, and Assesing. New York : Addison Wesley Longman, Icn.

Arends, Richard, I. (2008). Learning To Teach. Jakarta : Pustaka Belajar.

Arikunto, S. (2008). Prosedur Penelitian Suatu Pendekatan Praktek Edisi Revisi V. Jakarta: Rineka Cipta.

Arikunto, S. (2009). Dasar-Dasar Evaluasi Pendidikan Edisi Revisi. Jakarta: Bumi Aksara.

Asri, Budiningsih. (2004). Belajar dan Pembelajaran. Jakarta: Bumi Aksara.

Boeree, George. (2006). Personality Therories. Jogyakarta : Prismasophie.

Dalyono, M. (1996). Psikologi Pendidikan. Jakarta : Rhineka Cipta.

Depdikbud, (1994), Petunjuk Pelaksanaan Proses Belajar Mengajar. Jakarta: Dirjen Dikdasmen.

Departemen Agama Republik Indonesia. (2004). Pedoman Pendidikan Agama Buddha di Sekolah Umum. Jakarta : Dirjen Bimas Hindu dan Buddha.

Departemen Pendidikan Nasional. (2003). Standar Kompetensi Mata Pelajaran Pendidikan Agama Buddha SMA. Jakarta : Pusat Kurikulum, Balitbang Depdiknas.

Desmita. (2006). Psikologi Perkembangan. Bandung : PT. Remaja Rosdakarya.

Dhammananda, Sri. (2004). Be Happy. Jakarta : Pustaka Karaniya.

Dhammananda, Sri. (2005). Keyakinan Umat Buddha. Jakarta : Pustaka Karaniya.

Dick. W. and Carey. L (1996). The Systematic Design of Instuction. New York : Longman.

Dimyati dan Mudjiono. (2006). Belajar dan Pembelajaran. Jakarta : Rineka Cipta. 
Djaali. (2008). Psikologi Pendidikan. Jakarta : Bumi Aksara.

Duane Schultz and Sydney Ellen Schultz. (1994). Theories of Personality. Pasific Grove, California : Brooks/Cole Publishing Company.

Gagné R.M. and Briggs, L.J. (1979). Principles of Instructional Design. New York Holt : Rinehart and Winston.

Gagné R.M. (1985). The Condition of Learning and Theory of Instruction. New York Holt : Rinehart and Winston.

Hall, Calvin S. and Lindzey Garden. (2000). Teori-Teori Psikodinami. Yogyakarta : Kanisius.

Hamalik, O. (2008). Perencanaan Pengajaran Berdasarkan Pendekatan Sistem. Jakarta : Bumi Aksara.

Hamid, A. (2009). Teori Belajar dan Pembelajaran. Medan: Unimed.

Hariwijaya, M. (2005). Tes Kepribadian. Yogyakarta : Pustaka Pelajar.

Ibrahim, Muslimin. (2000). Pembelajaran Kooperatif. Surabaya : UNESA.

Isjoni. (2010). Cooperative Learning. Bandung : Alfabeta.

Joyce Bruce and Weil Marsha. (1986). Models of Teaching. New Delhi : Prentice Hall.

Kartono, Kartini. (2005). Teori Kepribadian. Jakarta : Mandar Maju.

Kesmapuri, E. (2006). Perbedaan Motif Sosial Pada Remaja dengan Kepribadian Ekstrovert dan Kepribadian Introvert. Skripsi, Universitas Guna Darma, (online) (http://gunadarma.ac.id), di akses pada tanggal 10 Februari 2011.

Khadaffi. (2005). Perbedaan Penerimaan Diri Pada Mahasiswa dengan Tipe Kepribadian Ekstrovert dan Introvert, Skripsi, Universitas Guna Darma, (online) (http://gunadarma.ac.id), di akses pada tanggal 22 Februari 2011.

Kunandar. (2007). Guru Profesional Implementasi Kurikulum Tingkat Satuan Pendidikan (KTSP) dan Persiapan Menghadapi Sertifikasi Guru. Jakarta: PT. Raja Grafindo Persada.

Lie, Anita. (2010). Cooperative Learning. Jakarta : Grasindo.

Margono, S. (2009). Metodologi Penelitian Pendidikan. Jakarta: Rineka Cipta.

Miarso, Yusufhadi. (2007). Menyemai Benih Teknologi Pendidikan. Jakarta: Kencana Prenada Media Group.
Narada, Bhikkhu. (1998). Sang Buddha dan Ajaran-ajaran-Nya Bagian 2. Jakarta: Yayasan Dhammadipa Arama.

Nasution, N. (1993). Psikologi Pendidikan. Jakarta : UT.

Nasution, S. (2008). Berbagai Pendekatan Dalam Proses Belajar dan Mengajar. Jakarta: Bumi Aksara.

Nurhikmah. (2007). Penerapan Model Pembelajaran Kooperatif Tipe Jigsaw Terhadap Hasil Belajar pada Materi Pokok Wujud Zat dan Perubahannya. Skripsi, Universitas Negeri Medan.

Peraturan Pemerintah Nomor 19 tahun 2005. Tentang Standar Nasional Pendidikan. Jakarta : Departemen Pendidikan Nasional.

Peraturan Pemerintah Nomor 24 tahun 2006. Tentang Pelaksanaan Standar Isi dan Standar Kompetensi Lulusan untuk Satuan Pendidikan Dasar dan Menengah. Jakarta : Departemen Pendidikan Nasional.

Peraturan Pemerintah Nomor 55 tahun 2007. Tentang Pendidikan Agama dan Pendidikan Keagamaan. Jakarta : Departemen Pendidikan Nasional.

Poerwadarminta, W.J.S. (1984). Kamus Umum Bahasa Indonesia. Jakarta : Balai Pustaka.

Raharjo, dkk. (2008). Cooperative Learning. Jakarta : P.T. Bumi Aksara.

Ratumanan, T.G. (2004) Belajar dan Pembelajaran. Surabaya : Unesa University Press.

Reigeluth, C. M. (1999). Instructional-Design Theories And Models : A New Paradigm of Instructional Theory Volume II. London : Lawrence Erlbaum Associates Publishers.

Reynolds D. and Muijs D. (2008). Effective Teaching. Yogyakarta : Pustaka Pelajar.

Rosalinda, A. (2006). Perbedaan Perilaku Nonasertif Berdasarkan Tipe Kepribadian Ekstrovert dan Introvert, pada Mahasiswa Universitas Gunadarma http://library.gunadarma.ac.id/diakses 10 Februari 2010.

Rusman. (2011). Model-model Pembelajaran Mengembangkan Profesionalisme Guru. Jakarta : PT. Raja Grafindo Perasada.

Sanders, D. H. (1990). Statistics A Fresh Approach. Singapore: McGraw-Hill International Edition. 
Sanjaya, Wina. (2008). Strategi Pembelajaran. Jakarta : Kencana.

Sanjivaputta, Jan. (pengalihbahasa). (1995) Kitab Suci Dhammapada. Thailand: LPD Publisher.

Sanjivaputta, Jan. (pengulas). (1990). Mangala Berkah Utama. Thailand: Penerbit Lembaga Pelestari Dhamma.

Slameto. (2010). Belajar dan Faktor-Faktor yang Mempengaruhinya. Jakarta : Bina Aksara.

Slavin, Robert E. (2009). Cooperative Learning : Teori, Riset dan Practik. Bandung : Penerbit Nusa Media.

Sri Esti Wuryani Djiwandono. (2002). Psikologi Pendidikan. Jakarta : PT. Grasindo.

Sudjana Nana, (2002). Metode Statistika. Bandung : Tarsito.

Sudjana Nana, (2005). Penilaian Hasil Proses Belajar Mengajar. Bandung : PT. Remaja Rosdakarya.
Sudrajat, Akhmad (2011). Hakikat Belajar (online). $\quad$ http://akhmadsudrajat. wordpress.com $/ 2008 / 01 / 31 /$ hakikatbelajar/, di akses pada tanggal 22 Februari 2011.

Suparman, M. A. (2001). Desain Instruksional. Jakarta.

Syafaruddin. (2008). Manajemen Pembelajaran. Jakarta : Quantum Teaching.

Undang-Undang Nomor 20 tahun 2003, Tentang Sistem Pendidikan Nasional, Jakarta : Departemen Pendidikan Nasional.

Winkel, W. S. (1991). Psikologi Pengajaran. Jakarta: Grasindo.

Sumadi Suryabrata. (2002). Psikologi Pendidikan. Jakarta : Raja Grafindo Persada.

Tim Psikologi. (2011). Buku Babon Psikotes Superlengkap. Jakarta : Visimedia. 